\title{
Hematologic response and serum and peritoneal fluid proteinogram of cattle affected by intestinal diseases and traumatic reticuloperitonitis
}

\section{Resposta hematológica e proteinograma sérico e do líquido peritoneal de bovinos acometidos com enfermidades intestinais e reticuloperitonite traumática}

\author{
Jomel Francisco dos Santos ${ }^{1 *}$; Rafael Otaviano do Rego ${ }^{2}$; José Augusto Bastos \\ Afonso $^{3}$; José Jurandir Fagliari4; Paulo Cesar Silva ${ }^{5}$; Pierre Castro Soares ${ }^{6}$; \\ Carla Lopes de Mendonça ${ }^{3}$
}

\section{Highlights}

Digestive diseases are among the main conditions that affect cattle.

Peritoneal fluid proteinogram can be affected due to digestive diseases.

Acute-phase proteins were good biomarkers in peritoneal fluid.

The $\alpha 1$-acid glycoprotein, haptoglobin, and transferrin are useful for diagnosis.

\begin{abstract}
This study aimed to evaluate the hematologic response and the serum and peritoneal fluid (PF) proteinogram of cattle affected by digestive diseases. Twenty-seven animals were distributed in two groups: GI (intestinal diseases) and GII (traumatic reticuloperitonitis, TRP). The animals were previously submitted to a physical exam. Subsequently, blood samples were collected to perform the complete blood count, determine the plasma protein and fibrinogen, and obtain the serum for proteinogram in polyacrylamide gel (SDS-PAGE). Simultaneously, PF was collected to perform physical and chemical evaluation and the electrophoretic

1 Prof. Dr., Instituto Federal de Educação, Ciência e Tecnologia do Amazonas, Campus Manaus Zona Leste, IFAM, CMZL, Manaus, AM, Brasil. E-mail: jomel.santos@ifam.edu.br

2 Prof. Dr., Universidade Federal do Espírito Santo, Campus Alegre, UFES, Alegre, ES, Brasil. E-mail: faelvet@yahoo. com.br

3 Médicos Veterinários, Clínica de Bovinos de Garanhuns, Campus Garanhuns, Universidade Federal Rural de Pernambuco, CBG, UFRPE, Garanhuns, PE, Brasil. E-mail: afonsojab@gmail.com; carlalopes.mendonca@gmail.com

${ }^{4}$ Prof. Dr., Faculdade de Ciências Agrárias e Veterinárias, Universidade Estadual Paulista Júlio de Mesquita Filho, UNESP, Campus de Jaboticabal, Jaboticabal, SP, Brasil. E-mail: fagliari@fcav.unesp.br

${ }^{5}$ Biólogo Dr., Faculdade de Ciências Agrárias e Veterinárias, UNESP, Campus de Jaboticabal, Jaboticabal, SP, Brasil. E-mail: paulocesar1958@bol.com.br

${ }^{6}$ Prof. Dr., Pesquisador, Departamento de Medicina Veterinária, DMV, UFRPE, Recife, PE, Brasil. E-mail: pcastro.pe@ gmail.com

* Author for correspondence
\end{abstract}

Received: Apr. 17, 2020 - Approved: Oct. 14, 2020 
profile (SDS-PAGE). ANOVA at the $5 \%$ probability level was used to compare the groups. The animals showed signs of apathy, dehydration, and gastrointestinal hypomotility in both groups. However, GI animals showed more significant clinical changes. The blood count of both groups $(P>0.05)$ showed leukocytosis due to neutrophilia and a regenerative left shift with hyperfibrinogenemia. The proteinogram of both body fluids allowed the identification of proteins albumin (ALB), transferrin (TRF), ceruloplasmin, haptoglobin, $\alpha 1$-acid glycoprotein ( $\alpha 1-A G P), M W 23000 \mathrm{Da}, \alpha 1$-antitrypsin, IgA, and IgG. The [PT] PF/[PT] blood serum ratio of each of the identified proteins increased, showing statistical differences between groups $(P<$ 0.05) regarding PT, ALB, TRF, $\alpha 1-A G P$, and IgG values, with $G$ animals showing the highest ratio. Intestinal diseases and TRP triggered a systemic and local response characterized by clinical, hematological, and serum and PF proteinogram alterations. The proteins $\alpha 1-G P A$, haptoglobin, and TRF measured in PF were good inflammation biomarkers and useful as an auxiliary tool for the diagnosis and prognosis of digestive diseases in cattle.

Key words: Cows. Acute-phase proteins. Digestive diseases. SDS-PAGE. Abdominal fluid.

\section{Resumo}

O objetivo deste estudo foi avaliar a resposta hematológica e o proteinograma sérico e do líquido peritoneal (LP) de bovinos acometidos com doenças digestivas. Foram avaliados 27 bovinos distribuídos em dois grupos, GI (enfermidades intestinais) e GII (reticuloperitonite traumática-RPT). Os animais foram previamente submetidos ao exame físico. Posteriormente foram colhidas amostras de sangue para realização do hemograma, determinação plasmática da proteína e do fibrinogênio e obtenção do soro para realização do proteinograma em gel de poliacrilamida (SDS-PAGE). Simultaneamente foi colhido o LP para avaliação física e química, assim como a realização do perfil eletroforético (SDS-PAGE). Empregou-se a análise de variância ao nível de $5 \%$ de probabilidade visando à comparação entre os grupos. Em ambos os grupos os animais demonstraram sinais de apatia, desidratação e hipomotilidade gastrointestinal, no entanto, os animais do GI apresentaram alterações clínicas mais expressivas. No hemograma observou-se em ambos os grupos $(P>$ $0,05)$ leucocitose por neutrofilia e desvio à esquerda regenerativo com hiperfibrinogenia. O proteinograma de ambos os fluidos corpóreos permitiu a identificação das proteínas albumina (ALB), transferrina (TRF), ceruloplasmina, haptoglobina, $\alpha$-1 glicoproteína ácida ( $\alpha 1-G P A), P M 23.000$ Da, $\alpha-1$ anti-tripsina, $\lg$ A e lgG. Os valores da relação [PT] LP / [PT] soro sanguíneo de cada uma das proteínas identificadas demonstrou elevação dos mesmos, bem como diferença estatística entre grupos $(P<0,05)$ nos valores da $P T, A L B, T R F$,

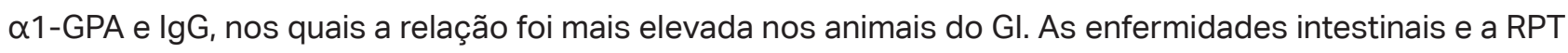
desencadearam resposta sistêmica e local caracterizada pelas alterações clínicas, hematológicas, e do proteinograma sérico e do LP. A $\alpha 1-G P A$, a haptoglobina e a TRF, mensuradas no LP se mostraram bons biomarcadores de inflamação, sendo úteis como recurso auxiliar de diagnóstico e prognóstico das doenças digestivas dos bovinos.

Palavras-chave: Vacas. Proteínas de fase aguda. Doenças digestivas. SDS-PAGE. Líquido abdominal. 


\section{Introduction}

Digestive diseases in cattle are among the most important disorders of this animal species worldwide (Radostits, Gay, Hinchcliff, \& Constable, 2007). A study pointed out that the occurrence of digestive disorders in cattle in a hospital routine in Brazil can reach 18\% (Afonso, 2017).

In addition to the physical exam, associated with animal history, the use of complementary tests is essential for the correct diagnosis. The analysis of peritoneal fluid (PF) is a good alternative for diagnostic aid when peritonitis is suspected (Hirsch \& Townsend, 1982; Radostits et al., 2007; Wittek, Grosche, Locher, \& Furll 2010b). Obstructive, traumatic, and/or inflammatory disease processes stand out among the diseases of the abdominal cavity indicated for the use of PF evaluation in cattle (Wittek et al., 2010b; Zadnik, 2010; Grosche, Locher, \& Furll 2012; Maden, Ozturk, Bulbul, Avci, \& Yazar, 2012).

In recent years, there has been a constant search in different animal species for more agile and accurate laboratory tests resulting from less invasive procedures, represented by biochemical and inflammatory indicators in different body fluids, including blood and PF (Borkowski et al., 2008; Ceciliani, Ceron, Eckersall, \& Sauerwein, 2012; Maden et al., 2012; Tharwat, Ali, Al-Sobayil, \& Buczinski, 2013). Recent studies have led to the identification of several proteins called acutephase proteins (APPs), synthesized against inflammatory stimuli. The quantification of APPs detects not only the presence of an inflammatory process but also indicates prognosis and/or monitors the individual response to instituted therapy (Eckersall, 2000; Tóthová, Nagy, \& Kovac, 2014). The intensity of the acute-phase response corresponds to the severity of the inflammatory and/or infectious process and tissue damage (Heegaard et al., 2000).

In dairy cattle, the higher emphasis has been placed on studies related to mastitis and diseases of the reproductive tract and hooves. However, information on abdominal diseases is scarce in the literature (Tóthová, Nagy, Kovac, \& Janciauskiene, 2013). Among the APPs evaluated in cattle, plasma fibrinogen has been highlighted as one of the most routines, with reports in cases of traumatic reticulopericarditis, traumatic reticuloperitonitis (TRP), differentiation of TRP with other gastrointestinal diseases, displacement of the abomasum (DA), and monitoring of postoperative complications (Hirvonen \& Pyörälä, 1998; Jawor, Stefaniak, Steiner, \& Baumgart, 2009; Câmara et al., 2010; N. A. A. Silva, 2011). Hirvonen and Pyörälä (1998) suggested the use of haptoglobin as a useful parameter in the diagnosis of TRP in dairy cows. Maden et al. (2012) observed an increase in the concentration of haptoglobin and serum amyloid $A$ in the blood of cows with DA.

Studies on the evaluation of APP in PF of cattle are even more scarce, with a limited number of evaluated proteins, such as haptoglobin and serum amyloid $A$ in $P F$ of cows with DA (Maden et al., 2012) and fibrinogen in cases of peritonitis (Wittek et al., 2010b). In Brazil, there is a lack of studies of these proteins in PF of adult cattle, with reports in calves due to abomasal puncture and in cases of umbilical hernia (Mendes et al., 2005; Soares, 2008).

Given the importance of knowledge and the use of new laboratory tools that aim to assist the diagnosis of diseases, combined 
with the lack of studies related to the evaluation of inflammatory biomarkers in digestive diseases in cattle, this study aimed to evaluate the hematologic response and the serum and PF proteinogram of dairy cattle affected by different digestive diseases.

\section{Material and Methods}

\section{Ethics committee}

This study obtained a favorable opinion from the Ethics Committee on the Use of Animals (CEUA) of the Federal Rural University of Pernambuco (UFRPE) under the number 044/2015.

\section{Animals}

Twenty-seven cattle affected by digestive diseaseswere dividedinto two groups: GI $(n=14)$ - intestinal diseases and GII $(n=13)$ - TRP and its complications. The two groups consisted of crossbred, adult dairy animals submitted to the semi-intensive system. All animals were submitted to clinical examination according to the recommendations of Dirksen, Gründer and Stöber (1993).

\section{Collection and storage of samples}

Blood samples were collected by external jugular venipuncture using a $25 \times 8-$ $\mathrm{mm}$ needle in Vacutainer $^{7}$ vacuum-sterilized silicone-coated tubes containing anticoagulant $\mathrm{K}_{3}$ EDTA (ethylenediaminetetraacetic acid) at $10 \%$ for hematologic examinations and tubes without anticoagulant to obtain the serum. After this procedure, blood serum samples were stored in an ultra-freezer ${ }^{8}\left(-80^{\circ} \mathrm{C}\right)$ for further analysis.

The PF was collected by performing an abdominocentesis in the caudoventral-lateral region between the mammary gland or testis and the stifle (flank fold), cranial to the right tibio-patellofemoral joint, and in the caudal region to the xiphoid cartilage of the sternum, four to ten centimeters laterally to the left of the linea alba, following the recommendations of Dirksen et al. (1993) and Divers and Peek (2008). The collection was carried out in sterile tubes without and with anticoagulant (10\% $\mathrm{K}_{3}$ EDTA) at volumes ranging from 10 to $20 \mathrm{~mL}$, using a $40 \times 12-\mathrm{mm}$ needle and guided by ultrasound ${ }^{9}$ whenever necessary. In the absence of in vivo $\mathrm{PF}$, the material was collected immediately after death and immediately after opening the abdominal cavity with criteria and rigor to avoid sample contamination.

\section{Laboratory processing}

Blood count and total plasma protein and fibrinogen were determined following the recommendations of Harvey (2012).

The PF analysis was performed just after collection, according to Zadnik (2010). The PF samples were initially submitted to physical

\footnotetext{
${ }^{7}$ Vacutainer, Becton Dickinson, Franklin Lakes, NJ, USA.

8 Ultralow freezer NuAire Inc., 2100 Fernbrook Lane N. Plymouth, MN 55447, USA.

${ }^{9}$ Ultrassom GE, modelo Logic 100 PRO, Av. Mario Coelho Aguiar, 215, São Luiz, São Paulo, SP, 05804-900.
} 
and chemical analysis. Protein concentration was determined by refractometry. ${ }^{10}$ Fibrinogen concentration was determined using the heat precipitation method (Harvey, 2012). Subsequently, the PF was centrifuged ${ }^{11}$ and the supernatant was stored in an ultra-freezer ${ }^{2}$ $\left(-80^{\circ} \mathrm{C}\right)$ to perform the proteinogram.

The separation of protein fractions from blood serum and PF was performed by sodium dodecyl sulfate-polyacrylamide gel electrophoresis (SDS-PAGE), as described by Laemmli (1970) and Fagliari and Silva (2002). The biuret ${ }^{12}$ method was used to determine the concentration of total blood serum and PF protein. PF samples in which the protein concentration was lower than the linearity of the test $(\leq 1.0 \mathrm{~g} / \mathrm{dL})$ were submitted to the pyrogallol ${ }^{13}$ red method. Readings were performed in a semi-automatic biochemistry analyzer ${ }^{14}$. The relationship between PF and serum concentrations was calculated for each protein using the following formula: [ptn in PF]/ [ptn in blood serum].

The statistical analysis consisted of a comparison between groups for the hematologic values and the relationship between the PF and blood serum protein concentrations of each of the identified proteins. Initially, the data were tested for normal distribution using the KolmogorovSmirnov test. The data that did not meet the assumptions of normality and homogeneity were submitted to logarithmic transformation $(\log X+1)$ or the square root [SR $(X+1 / 2)]$. Subsequently, they were submitted to analysis of variance (F-test). The data were analyzed using the General Linear Model (GLM) procedure of the computer program Statistical Analyses Sistem Institute [SAS Institute], 2009). The $5 \%$ probability level was adopted for all statistical analyses.

\section{Results}

Digestive diseases

Casesofenteritis(4/14), intussusception (3/14), phytobezoar obstruction (2/14), small bowel torsion (2/14), ulcerative colitis (2/14), and mesenteric abscess (1/14) were diagnosed among animals with intestinal diseases. Traumatic reticuloperitonitis (TRP) (6/13), traumatic reticulopericarditis (5/13), traumatic reticulohepatitis (1/13), and traumatic reticulomyocarditis $(1 / 13)$ were diagnosed in animals with TRP and its complications.

\section{Clinical findings}

The frequencies of the main clinical findings and characteristics of feces observed in each group are shown in Table 1.

\footnotetext{
${ }^{10}$ Refratômetro portátil Mod. RTP-20 ATC.

${ }^{11}$ Centrífuga Fanem Ltda Baby I, Mod. 206. Av. General Ataliba Leonel 1790, São Paulo, SP, Brasil.

12 Proteína Total, Labtest Diagnóstica S.A., Av. Paulo Ferreira da Costa 600, Lagoa Santa, MG 33400-000, Brasil.

${ }^{13}$ Sensiprot, Labtest Diagnóstica S.A., Av. Paulo Ferreira da Costa 600, Lagoa Santa, MG 33400-000, Brasil.

${ }^{14}$ Labquest Bio 2000, Labtest Diagnóstica S.A, Lagoa Santa, MG.
} 
Table 1

Frequency of clinical findings and characteristics of feces observed in cattle affected by intestinal diseases and traumatic reticuloperitonitis and its complications (TRP)

\begin{tabular}{|c|c|c|}
\hline \multirow{2}{*}{ Clinical finding } & \multicolumn{2}{|c|}{ Digestive disease } \\
\hline & Intestinal disease (\%) & TRP (\%) \\
\hline Behavior & $\begin{array}{l}\text { Apathetic (85.75) } \\
\text { Calm (7.15) } \\
\text { Agitated (7.15) }\end{array}$ & $\begin{array}{l}\text { Apathetic (53.85) } \\
\text { Calm (46.15) }\end{array}$ \\
\hline Appetite & $\begin{array}{l}\text { Absent (64.30) } \\
\text { Wayward (21.40) } \\
\text { Present (14.30) }\end{array}$ & $\begin{array}{c}\text { Present (46.15) } \\
\text { Absent (30.75) } \\
\text { Wayward (23.10) }\end{array}$ \\
\hline Degree of dehydration & $\begin{array}{c}\text { NC (7.15) } \\
\text { Discreet (14.30) } \\
\text { Moderate (42.85) } \\
\text { Moderate to intense (35.70) }\end{array}$ & $\begin{array}{c}\text { NC (23.07) } \\
\text { Discreet (23.07) } \\
\text { Moderate (38.46) } \\
\text { Intense (15.40) }\end{array}$ \\
\hline Rectal temperature $\left({ }^{\circ} \mathrm{C}\right)$ & $\begin{array}{c}<38(28.57) \\
38-39(42.86) \\
>39(28.57)\end{array}$ & $\begin{array}{c}<38(28.57) \\
38-39(46.15) \\
>39(25.28)\end{array}$ \\
\hline Heart rate (*bpm) & $\begin{array}{c}40-60(14.28) \\
60-80(35.71) \\
80-100(42.85) \\
>100(7.16)\end{array}$ & $\begin{array}{c}40-60(30.76) \\
60-80(23.07) \\
80-100(30.76) \\
>100(15.41)\end{array}$ \\
\hline $\begin{array}{l}\text { Respiratory frequency } \\
\text { (*mrpm) }\end{array}$ & $\begin{array}{l}24-36(71.42) \\
36-50(28.58)\end{array}$ & $\begin{array}{c}24-36(46.15) \\
36-50(23.07) \\
>50(30.78)\end{array}$ \\
\hline $\begin{array}{l}\text { Ruminal motility } \\
\text { (observation time } \\
\text { between } 2 \text { to } 5 \text { minutes) }\end{array}$ & $\begin{array}{l}\text { Atony }(21.42) \\
\text { Borborygmi }(7.12) \\
\begin{array}{l}(+)(+)-(35.73) \\
++-(35.73)\end{array}\end{array}$ & $\begin{array}{l}\text { Atony }(15.40) \\
\text { Borborygmi }(7.60) \\
\begin{array}{l}(+)(+)(46.15) \\
++-(30.76)\end{array}\end{array}$ \\
\hline Abdominal tension & $\begin{array}{l}\text { Physiological (35.72) } \\
\text { Increased (64.28) }\end{array}$ & $\begin{array}{l}\text { Physiological (84.60) } \\
\text { Increased (15.40) }\end{array}$ \\
\hline Intestinal motility & $\begin{array}{l}\text { Hypomotility (71.45) } \\
\text { Physiological (28.55) }\end{array}$ & $\begin{array}{l}\text { Hypomotility (76.92) } \\
\text { Physiological (23.08) }\end{array}$ \\
\hline $\begin{array}{l}\text { Ballottement (splashing } \\
\text { sound) }\end{array}$ & $\begin{array}{l}\text { Yes (35.72) } \\
{ }^{*} \mathrm{NC}(64.28)\end{array}$ & $\begin{array}{l}\text { Yes }(7.70) \\
{ }^{*} \mathrm{NC}(92.30)\end{array}$ \\
\hline Feces characteristics & $\begin{array}{c}\text { Not observed (35.72) } \\
\text { Dark and fetid (21.42) } \\
\text { Scarce with mucus (21.44) } \\
\text { Mucus with blood (7.14) } \\
\text { Physiological (7.14) } \\
\text { Absence of feces (7.14) }\end{array}$ & $\begin{array}{c}\text { Not observed (23.08) } \\
\text { Physiological (23.08) } \\
\text { Diarrheal (23.08) } \\
\text { Dry (30.76) }\end{array}$ \\
\hline
\end{tabular}

(+) incomplete movement; + complete movement; - absence of movement; NC no change. 


\section{Hematologic response}

The results of the hematologic evaluation of cattle affected by digestive diseases (intestinal diseases and traumatic reticuloperitonitis and its complications) are shown in Table 2.

\section{Table 2}

Mean value, standard deviation $(x \pm s)$, and significance level $(P)$ of the hematological variables observed in cattle affected by intestinal diseases and traumatic reticuloperitonitis and its complications (TRP)

\begin{tabular}{|c|c|c|c|c|}
\hline \multirow{2}{*}{ Hematologic variables } & \multicolumn{2}{|c|}{ Digestive disease } & \multirow{2}{*}{ Overall average } & \multirow{2}{*}{$P$} \\
\hline & Intestinal & TRP & & \\
\hline Hematocrit (\%) & $27.0 \pm 8.54^{A}$ & $29.0 \pm 6.36^{A}$ & 28.0 & 0.5436 \\
\hline Red blood cell count $\left(\times 10^{6}\right)$ & $6.29 \pm 2.44^{\mathrm{A}}$ & $5.97 \pm 1.35^{A}$ & 6.14 & 0.6805 \\
\hline Hemoglobin (g/dL) & $9.45 \pm 3.06^{A}$ & $9.66 \pm 2.15^{A}$ & 9.55 & 0.8338 \\
\hline $\operatorname{MCV}(f L)$ & $48.64 \pm 6.18^{A}$ & $49.07 \pm 4.04^{\mathrm{A}}$ & 48.85 & 0.8337 \\
\hline $\mathrm{MCHC}(\%)$ & $32.64 \pm 1.67^{\mathrm{A}}$ & $33.14 \pm 2.51^{\mathrm{A}}$ & 32.88 & 0.5451 \\
\hline Total leukocytes (/uL) & $17.198 \pm 10.627^{A}$ & $22.373 \pm 14.515^{A}$ & 19.690 & 0.2981 \\
\hline 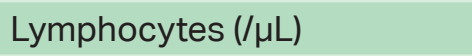 & $4.676 \pm 1.965^{A}$ & $5.849 \pm 5.184^{A}$ & 5.241 & 0.4375 \\
\hline Segmented neutrophils (/ $\mu \mathrm{L})$ & $11.207 \pm 9.172^{A}$ & $15.582 \pm 13.585^{A}$ & 13.314 & 0.3329 \\
\hline Rod neutrophils (/ $\mu \mathrm{L})$ & $1.057 \pm 1.644^{\mathrm{A}}$ & $508 \pm 624^{A}$ & 792 & 0.2698 \\
\hline Eosinophils $(/ \mu \mathrm{L})$ & $34 \pm 83^{A}$ & $222 \pm 446^{A}$ & 125 & 0.1337 \\
\hline Monocytes $(/ \mu \mathrm{L})$ & $196 \pm 254^{A}$ & $169 \pm 212^{A}$ & 183 & 0.7671 \\
\hline Basophils $(/ \mu \mathrm{L})$ & $6 \pm 21^{A}$ & $\mathrm{O}^{\mathrm{A}}$ & 3 & 0.3451 \\
\hline TPP (g/dL) & $6.42 \pm 1.32^{\mathrm{B}}$ & $7.63 \pm 1.62^{\mathrm{A}}$ & 7.00 & 0.0424 \\
\hline $\mathrm{PF}$ (mg/dL) & $743 \pm 318^{A}$ & $715 \pm 380^{A}$ & 730 & 0.8399 \\
\hline
\end{tabular}

MCV: mean corpuscular volume; MCHC: mean corpuscular hemoglobin concentration; TPP: total plasma protein; PF: plasma fibrinogen. Means followed by different letters in the same row differ from each other at the $5 \%$ probability level.

Physical and chemical analysis of peritoneal fluid

Regarding the aspect (degree of turbidity), all PF samples were slightly turbid or turbid. Color varied from light yellow to amber and the approximate collected volume ranged from 10 to $20 \mathrm{~mL}$. Density ranged from 1,010 to 1,040 . The odor was mostly unchanged in samples from both groups.
Protein concentration showed mean values of $4.36 \pm 1.88$ and $3.12 \pm 1.95 \mathrm{~g} / \mathrm{dL}$ in $\mathrm{Gl}$ and GII, respectively. A total of $70.37 \%(19 / 27)$ of the samples showed values of fibrinogen concentration in the PF of both groups below $100 \mathrm{mg} / \mathrm{dL}$. 


\section{Proteinogram}

\section{Blood serum}

The SDS-PAGE procedure showed the fractionation of up to 24 proteins in the blood serum of cattle affected by digestive diseases, whose molecular weights ranged from 22,000 to 184,000 Daltons (Da). The following APPs (positive and negative) were considered of clinical interest: albumin, ceruloplasmin, haptoglobin, transferrin, $\alpha 1$-acid glycoprotein, MW 23,000 Da, and immunoglobulins IgG and $\lg \mathrm{A}$.

Peritoneal fluid (PF)

The fractionation of up to 24 proteins was observed in the PF of cattle affected by digestive diseases, whose molecular weights ranged from 22,000 to $171,000 \mathrm{Da}$. Seven APPs (positive and negative) were identified nominally:albumin, ceruloplasmin, haptoglobin, transferrin, $\alpha 1$-acid glycoprotein, MW 23,000 $\mathrm{Da}$, and immunoglobulins $\lg \mathrm{G}$ and $\lg \mathrm{A}$. Only one $\mathrm{Gl}$ animal presented $\alpha 1$-antitrypsin.

\section{Protein concentration [PT] PF/[PT] blood serum ratio}

The results of the [PT] peritoneal fluid (PF)/[PT] blood serum ratio, in which [PT] represents the protein concentration, is shown in Table 3.

Table 3

Mean value, standard deviation $(x \pm s)$, and significance level $(P)$ of the [PT] peritoneal fluid/[PT] blood serum ratio of the different proteins identified in the proteinogram (SDS-PAGE) of the cattle affected by intestinal diseases and traumatic reticuloperitonitis and its complications (TRP)

\begin{tabular}{lcccc} 
& \multicolumn{2}{c}{ Digestive disease } & Overall average & P \\
\cline { 2 - 3 } Protein & Intestinal & TRP & 0.56 & 0.0327 \\
Total protein (TP) & $0.67 \pm 0.23^{\mathrm{A}}$ & $0.43 \pm 0.27^{\mathrm{B}}$ & 0.57 & 0.0259 \\
Albumin (ALB) & $0.68 \pm 0.23^{\mathrm{A}}$ & $0.43 \pm 0.26^{\mathrm{B}}$ & 0.57 & 0.1723 \\
Ceruloplasmin (CRPL) & $0.57 \pm 0.27^{\mathrm{A}}$ & $0.41 \pm 0.25^{\mathrm{A}}$ & 0.51 & 0.2096 \\
Haptoglobin (HP) & $1.03 \pm 0.68^{\mathrm{A}}$ & $0.69 \pm 0.43^{\mathrm{A}}$ & 0.88 & 0.0149 \\
Transferrin (TRF) & $0.63 \pm 0.31^{\mathrm{A}}$ & $0.33 \pm 0.19^{\mathrm{B}}$ & 0.49 & 0.0432 \\
$\alpha 1-A G P$ & $1.04 \pm 0.84^{\mathrm{A}}$ & $0.42 \pm 0.37^{\mathrm{B}}$ & 0.75 & 0.0681 \\
MW 23.000 Da & $0.76 \pm 0.45^{\mathrm{A}}$ & $0.43 \pm 0.35^{\mathrm{A}}$ & 0.61 & 0.0371 \\
$\operatorname{lgG}$ & $0.68 \pm 0.26^{\mathrm{A}}$ & $0.44 \pm 0.24^{\mathrm{B}}$ & 0.57 & 0.9731
\end{tabular}

[Protein concentration]; $\alpha 1$-AGP: $\alpha 1$-acid glycoprotein; IgG: immunoglobulin G; IgA: immuno-globulin A. Means followed by different letters in the same row differ from each other at the $5 \%$ probability level.

Da: Dalton 


\section{Discussion}

Digestive diseases triggered a focal (22.2\%) or diffuse $(77.8 \%)$ peritonitis, resulting in clinical changes observed in both groups, with higher intensity in the group with intestinal diseases. Apathy and inappetence in both groups were more expressive in $\mathrm{Gl}$, as also reported by Dezfouli et al. (2012) in animals with peritonitis resulting from abdominal disorders and liver diseases. According to Lascelles (1996), these findings may be related to pain.

Dehydration, observed in a high number of animals with intestinal diseases, can be attributed to the increased loss of blood fluid, as occurs in intestinal obstruction, causing the sequestration of fluid in the digestive system and potentiating the degree of dehydration of these animals (Smith, 2015), as also described by Silva, Afonso, Souza, Costa and Mendonça (2010) in cattle with intussusception.

The vast majority of animals in both groups remained with body temperature within the normal range for the species (Dirksen et al., 1993), as also observed by Afonso et al. (2008), Athar, Mohindroo, Singh, Kumar and Randhawa (2010), A. P Silva et al. (2010), and N. A. A. Silva (2011).

Tachycardia, present in the animals of both groups, was evidenced by Afonso et al. (2008) and N. A. A. Silva (2011) as one of the most frequent clinical signs in animals with intestinal obstruction by phytobezoar and TRP, respectively. Tachypnea was a more significant finding in animals with TRP and its complications (GII) compared to GI, diverging from Athar et al. (2010) and N. A. A. Silva (2011), who observed a normal respiratory rate in most animals with TRP. According to Dirksen et al, (1993), tachypnea can be observed in animals with distention of pre-stomachs and in cases of ascites. Lascelles (1996) attributed the increase in heart and respiratory rates to visceral pain, a finding also cited by Dezfouli et al. (2012) in most animals with peritonitis.

Most of the animals presented ruminal and intestinal hypomotility, showing an increase in abdominal tension]and the presence of a splashing sound on ballottement in $\mathrm{Gl}$, being also present in a low number of Gll animals. Braun et al. (2012) observed the splashing sound on ballottement in $82.6 \%$ of the cattle with cecum dilatation. Hussain, Uppal, Randhawa, Sood and Bovine (2015) observed similar clinical signs in cattle and buffaloes with intestinal obstruction and described that digestive hypomotility may have occurred due to inflammation of the peritoneum. According to Athar et al. (2010), ruminal hypomotility may result from the location of the foreign body in the reticulum.

Feces presented mucus, blood, and dark color and fetid characteristics in GI animals, as similarly reported by A. P. Silva et al. (2010).

\section{Hematologic response}

Animals in both groups presented no anemia. The hematocrit parallel to TPP showed hypoproteinemia in GI.More than half of the evaluated cattle had a moderate to intense degree of dehydration (Table 1), which makes TPP and hematocrit values overestimated, as also described by Russell and Roussel (2007) in animals affected by TRP. Hypoproteinemia can be attributed to the loss of albumin in acute or subacute gastrointestinal disorders. Protein migration is due to the increase in vascular permeability triggered by the inflammatory 
process, causing its migration to the injury site in the abdominal cavity (Jones, Hunt, \& King 2000; Kaneko, Harvey, \& Bruss, 2008).

Both groups presented leukocytosis by neutrophilia with a regenerative left shift. Cattle with intestinal obstruction by phytobezoar (Afonso et al., 2008) and animals with TRP (Reddy, Reddy, Naik, \& Prasad, 2014) had a leukocyte response similar to that of this study. This type of response in cattle is commonly found in cases of chronic clinical evolution, but an acute inflammatory reaction, i.e., an acute inflammatory pattern is present in animals with prolonged inflammatory processes, as long as the demand for neutrophils in the affected tissue remains active utilizing inflammatory mediators (Jain, 1993). Afonso et al. (2002) reported that cases of cecum dilatation led to circulatory and inflammatory disorders that cause the leukocyte response to be more intense, especially in the case of organ torsion. Hussain et al. (2015) reported a case of intestinal obstruction in cattle and found that the increase in the immature neutrophil count could be associated with ischemic intestinal necrosis, also observed in some animals (71.4\%) of this study, characterized by the left shift.

The hyperfibrinogenemia observed in animals of both groups has been reported in studies associated with intestinal diseases (Afonso et al., 2002, 2008, 2009; Hussain \& Uppal, 2014), such as in TRP (Athar et al., 2010; Habasha \& Yassein, 2014; Reddy et al., 2014). Plasma fibrinogen, despite being a positive acute-phase protein, can remain high in chronic processes as long as the antigenic stimulus and the capacity for hepatic synthesis are maintained (Jain, 1993).

\section{Peritoneal fluid}

The increase in PF volume observed in animals with digestive diseases was also reported by Zadnik (2010) in cattle in a similar situation. Wittek et al. (2010b) identified a significant PF volume in cattle with peritonitis compared to the volume collected in healthy animals. Physiopathologically, the mechanism of fluid accumulation in the cavities may be due to a decrease in oncotic pressure and an increase in vascular permeability (Dewhurst \& Papasouliotis, 2005), occurring in chronic diseases and/or obstructive digestive processes. Divers and Peek (2008) reported the clinical suspicion of peritonitis and observed alteration of the abdominal contour and splashing sound on ballottement, suggesting an increase in the PF volume, as also observed in this study in most animals of both groups.

The change in PF color associated with turbidity intensity is similar to the results obtained by Dezfouli et al. (2012). The darker and/or more intense PF color is suggestive of the involvement of the abdominal cavity. The normality pattern in cattle is given by its clear aspect, ranging from colorless to straw yellow (Dirksen et al., 1993; Wittek et al., 2010b; Zadnik, 2010), thus characterizing the physical alteration of this variable in this study. In general, PF density values of both groups were higher than 1,015, that is, higher than those indicated by Dirksen et al. (1993) in healthy cattle and similar to the mean value of 1,027 described by Dezfouli et al. (2012) when evaluating PF in cattle with peritonitis. Peiró et al. (2009) attributed the increase in PF density to the local inflammatory process installed in the abdominal cavity when compared to healthy animals. Zadnik (2010) demonstrated that an increase in PF density was related to 
the clinical severity of digestive disorders, considering that the higher the density, the more compromised the PF was.

The protein concentration of PF revealed mean values above $3.0 \mathrm{~g} / \mathrm{dL}$ in both groups, characterizing its alteration compared to the normal values for the species (Wittek, Grosche, Locher, Alkaassem, \& Furll, 2010a). Dezfouli et al. (2012) worked with animals with peritonitis and found a mean protein concentration higher than $4.0 \mathrm{~g} / \mathrm{dL}$. Peiró et al. (2009) observed an increase in the protein concentration in the PF of calves submitted to herniorrhaphy, which was attributed to the local inflammatory process that led to a change in vascular permeability, causing leakage and increase in the concentration of proteins in the inflammation sites (Dewhurst \& Papasouliotis, 2005).

The fibrinogen concentration in PF presented mean values below $100 \mathrm{mg} / \mathrm{dL}$, considered in the normal range (Wittek et al., $2010 a, b)$, that is, fibrinogen was not a good biomarker to detect the inflammatory process in the abdominal cavity of cattle under the clinical situations observed in this study. It may be the result of the animal ability to limit the inflammation/infection sites (focal peritonitis) through fibrin establishment and binding, leading to increased consumption of this protein, as its formation requires a complex involvement of interactions between proteases and their cofactors to originate thrombin, which converts soluble fibrinogen into insoluble fibrin by proteolysis (Smith, 2015). Clinical-surgical cases have detected an increase in fibrinogen evaluated in the PF of calves undergoing herniorrhaphy, in which the magnitude of the response was generally related to the degree of invasiveness and duration of the surgical procedure (Peiró et al., 2009).

\section{Proteinogram}

The serum electrophoretogram and PF analysis showed an increase in the [PT] $\mathrm{PF} /[\mathrm{PT}]$ blood serum ratio of both groups with digestive diseases, being significantly higher in GI animals (0.67), as also observed by Wittek et al. (2010b) in cows with peritonitis. This ratio varies from 0.29 to 0.34 in healthy cattle, as observed by Wittek et al. (2010a,b), and Maden et al. (2012). Ratio values higher than normal for the species resulted from an increased protein concentration in the PF of both groups, but in higher intensity in GI. This result can be justified by the impairment of the integrity of the intestinal wall, changing the vascular permeability, and the inflammatory response (Dewhurst \& Papasouliotis, 2005; Peiró et al., 2009).

The response of the albumin fraction was similar to that of PT with regard to the increase of its concentration in PF, reflected in the increased ratio in both groups, being higher in $\mathrm{Gl}$ and higher than that reported by Soares (2008) in healthy calves. Albumin increased in PF although it is a negative APP, with a consequent increase in the ratio. Nogueira, Filippo, Anai, Santana and Campos (2010) attributed the increase in the albumin concentration in the PF of horses with intestinal obstruction to the inflammatory process in the abdominal cavity, behaving as a positive APP. Abdominal diseases such as those observed in this study can trigger increased vascular permeability and the consequent leakage of this protein into the cavity, considering that this protein is found in a higher percentage in body fluids (Eckersall, 2008).

Ceruloplasmin (CRPL) in blood serum had a mean concentration of $226.01 \pm 95.05$ $\mathrm{mg} / \mathrm{dL}$ in Gl and of $232.48 \pm 136.22 \mathrm{mg} / \mathrm{dL}$ in GIl. 
The mean APPs in healthy Girolando and Nellore cows were 38.6 and 29.2 mg/dL (Conceição et al., 2015). Simplício, Sousa, Fagliari and Silva (2013) observed that CRPL significantly increased its serum concentrations in cattle affected by acute diseases, stating that this protein is a good inflammatory marker. According to Segelmark, Persson, Hellmark and Wieslandes (1997), this protein can act as an anti-inflammatory agent, reducing the neutrophil adhesion to the endothelium and acting as a peroxidase destroyer. The [CRPL] $\mathrm{PF} /[\mathrm{CRPL}]$ blood serum ratio showed no significant difference between groups, but the overall average ratio of 0.14 was higher than that found in healthy calves (Soares, 2008). This author also evaluated CRPL in the PF of calves with an umbilical hernia and observed the primary increase in the concentration of this APP in PF and later in the plasma, which was attributed to the local inflammatory stimulus, as also described by Peiró et al. (2009). According to Collins (2000), the occurrence of inflammatory processes leads to an increase in vascular permeability and consequent leakage and an increase of proteins to the inflammation site, which may be the cause of the increase in CRPL concentration in the PF of cattle affected by digestive diseases.

In the present study, the concentration of serum haptoglobin (HP) showed mean values of $35.83 \pm 24.53 \mathrm{mg} / \mathrm{dL}$ in $\mathrm{Gl}$ and 51.49 $\pm 46.47 \mathrm{mg} / \mathrm{dL}$ in Gll. Conceição et al. (2015) used SDS-PAGE and found serum HP values of $4.6 \mathrm{mg} / \mathrm{dL}$ in Girolando cows and $16.4 \mathrm{mg} / \mathrm{dL}$ in healthy Nellore cows. The serum concentration is usually low or even undetectable in healthy animals (Eckersall et al., 2001), but expressive increases can be detected under pathological situations (Conner, Eckersall, Wiseman, Aitchison \& Douglas, 1988).
The values of the [HP] PF/[HP] blood serum ratio were higher in $\mathrm{Gl}$ (1.03) and GII (0.69) (Table 3) than those found in healthy cows (0.38) and calves (0.19) (Soares, 2008; Maden et al., 2012). The value of this ratio was higher than 1.0 in Gl although no significant difference was observed between the evaluated groups. In this case, HP concentration in PF was higher than that of blood serum. Different studies with cattle have evaluated the response of this protein in blood and milk, especially those related to the mammary gland (Grönlund, Sandgren, \& Persson, 2005), respiratory tract (Heegaard et al., 2000), diarrhea in calves (G. D. Silva et al., 2011), hoof diseases (Jawor, Steiner, Stefaniak, Baumgartner, \& Rzasa, 2008), reproductive diseases (Chan, Chang, Hsu, Liu, \& Chen, 2010), and some specific studies related to abdominal disorders (Tóthová et al., 2013). However, studies measuring haptoglobin in the PF of cattle with digestive diseases, mainly intestinal diseases and TRP and its complications, are scarce in the literature. The expressive increase of this protein in the PF of animals with TRP, especially in animals with intestinal diseases, can be a valuable diagnostic and prognostic resource, particularly in cases not yet clinically defined. In ruminants, HP is considered the main protein of acute-phase response unlike other animal species (Eckersall \& Bell, 2010).

Serum transferrin (TRF) presented mean values of $193.61 \pm 88.80 \mathrm{mg} / \mathrm{dL}$ in $\mathrm{Gl}$ and $249.72 \pm 134.73 \mathrm{mg} / \mathrm{dL}$ in Gll, which are close to the values reported by Simplício (2011) when working with healthy cattle. However, the [TRF] PF/[TRF] blood serum ratio was significantly higher in $\mathrm{Gl}$, but with higher values in both groups than that found by Soares (2008) in healthy calves (0.20). According to Gruys, Obwolo and Toussaint (1994), transferrin is 
a negative APP that should not increase in inflammatory processes without infection. In the present study, the reverse was observed in $\mathrm{PF}$, i.e., this protein was high in both groups, particularly in animals affected by intestinal diseases. Soares (2008) also reported an increase in transferrin concentration in PF in calves with the hernia. Nogueira et al. (2010) and Nogueira, Di Filippo, Anai, Pereira and Santana(2013) also observed an increase in this APP in the PF of horses with experimental intestinal obstructions, which was attributed to an inflammatory lesion resulting from the surgical procedure and the enteric lesion, giving a positive APP behavior in PF.

Digestive diseases probably increased this APP in the PF of animals evaluated this study, particularly in intestinal obstructions, intussusceptions, and other diseases that affected the digestive system. In this sense, Nogueira et al. (2013) confirmed that the evaluation of PF is more sensitive and effective in the diagnosis and monitoring of abdominal inflammatory processes in the equine species than the serum evaluation.

The mean value of $\alpha 1-A G P$ in blood serum was $32.64 \pm 27.56 \mathrm{mg} / \mathrm{dL}$ in $\mathrm{Gl}$ and 58.12 $\pm 51.73 \mathrm{mg} / \mathrm{dL}$ in Gll, characterizing the increase of this protein in the serum of the studied animals compared to Simplício et al. (2013), who found an overall average of $15.21 \mathrm{mg} / \mathrm{dL}$ in healthy cattle, and Conceição et al. (2015), who found $15.6 \mathrm{mg} / \mathrm{dL}$ in healthy Nellore cows and $16.3 \mathrm{mg} / \mathrm{dL}$ in healthy Girolando cows. Murata, Shimada and Yoshioka (2004) stated that $\alpha 1-A G P$ is an important biomarker in the clinical follow-up of inflammatory processes in cattle, contrasting with the reports by Hirvonen (2000), who mentions that this protein has a moderate to low response relative to tissue damage in cattle.
In addition to the serum increase of this protein, its increase was also observed in $\mathrm{PF}$, as shown in the increased value of the [ $\alpha 1-$ AGP] $P F /[\alpha 1-A G P]$ blood serum ratio in both studied groups, which was higher than the value observed in healthy calves $(0.18)$ (Soares, 2008). The values of this ratio were higher (equal to one) in the group of animals with intestinal diseases. Soares (2008) observed a significant increase in the $\alpha 1-A G P$ in the PF of calves submitted to herniorrhaphy and reported that the surgical procedure, especially the healing process of the surgical incision, was possibly the cause of the increase in this APP since there was no associated infectious process. The values found in the PF of $\mathrm{Gl}$ animals were higher than those observed by Soares (2008), which could be justified by the local impairment caused by intestinal diseases, that is, the more severe the injury, the higher the stimulus (Heegaard et al., 2000). Nogueira et al. (2013) also observed an increase in $\alpha 1-A G P$ in the PF of horses with intestinal obstructions and a consequent increase in the ratio of this APP. The $\alpha 1-A G P$ can assist in the removal of lipopolysaccharides (LPS) from the circulation by the direct binding with them, neutralizing toxicity, as justified by Moore, Rosenfeld, Gribbon, Winlove and Tsai (1997). According to Nogueira et al. (2013), this finding has a great value in the evaluation of horses with colic, given that gastrointestinal disorders favor the transfer of bacteria and toxins from the intestinal lumen to the bloodstream, which contributes to the occurrence of septic shock.

The APP MW 23,000 Da was detected in the blood serum and PF of cattle in the present study, with serum values below the value found in healthy cows (Conceição et al., 2015). This protein probably behaves as a negative acutephase, as also reported by Macedo et al. 
(2017), who worked with sheep diagnosed with pregnancy toxemia.

Studies on this APP in the blood are still scarce, with few reports in Brazil on goat and cattle (Saut et al., 2009; Conceição et al., 2015) and sheep (Lemos, 2011; Campos, 2014; Macedo et al., 2017), and nonexistent in PF. Thus, more research is required for a better understanding of this APP.

The immunoglobulin IgA had a similar $[\lg A] \mathrm{PF} /[\lg \mathrm{A}]$ blood serum ratio in both groups, while IgG presented a significantly higher ratio in Gl. Nogueira et al. (2013) observed in the equine species that the ratio for both $\lg \mathrm{A}$ and IgG increased significantly in horses submitted to intestinal obstruction. Barros (2016) also observed an increase in the concentrations of these proteins in PF and a consequent increase in the ratios in donkeys submitted to ovariectomy. The increased concentrations of these immunoglobulins ( $\lg A$ and $\lg G$ ) may be related to the local antigenic stimulus triggered by digestive diseases, as well as due to surgical interventions (Peiró et al., 2009). According to Eckersall (2008), the increase in the production of IL-6 and other interleukins, which may cause unspecific polyclonal activation of $B$ cells, results in the production of antibodies from different sources.

\section{Conclusion}

Intestinal diseases and traumatic reticuloperitonitis and its complications induced a systemic and local response characterized by clinical, hematologic, and proteinogram changes in the blood and peritoneal fluid. Higher intensity of the acutephase response was found in animals with intestinal diseases. $\alpha 1$-acid glycoprotein, haptoglobin, and transferrin measured in the peritoneal fluid were good biomarkers of inflammatory processes, being useful in the diagnosis and prognosis of digestive diseases in cattle.

\section{Acknowledgments}

To the Fundação de Amparo à Ciência e Tecnologia of the State of Pernambuco (FACEPE) for granting of the doctoral scholarship (IBPG No. 0586-5.05/13/1).

\section{References}

Afonso, J. A. B. (2017). Afecções intestinais em bovinos. Revista Acadêmica Ciência Animal, 15(2), 15-20. doi: 10.7213/ acadêmica.15.S02.2017.A03

Afonso, J. A. B., Mendonça, C. L., Costa, N. A., Souza, M. I., Simão, L. C. V., \& Dantas, F. R. (2002). Alterações clínicas e laboratoriais na dilatação do ceco em bovinos. Análise de 10 casos. Revista de Educação Continuada CRMV-SP, 5(3), 313-320. doi: 10.36440/recmvz.v5i3.3298

Afonso, J. A. B., Pereira, A. L. L., Vieira, A. C. S., Mendonça, C. L., Costa, N. A., \& Souza, M. I. (2008). Alterações clínicas e laboratoriais na obstrução gastrintestinal por fitobezoários em bovinos. Revista Brasileira de Saúde e Produção Animal, 9(1), 91-102.

Afonso, J. A. B., Souza, J. C. A., Guaraná, E. L. S., Mendonça, C. L., Costa, N. A., \& Rego, R. O. (2009). Compactação do cólon em vaca. Relato de caso. Ciência Animal Brasileira, 1, 1-7. doi: 10.1590/S0100736X2016000800007 
Athar, H., Mohindroo, J., Singh, K., Kumar, A., \& Randhawa, C. S. (2010). Clinical, haematobiochemical, radiographic and ultrasonographic features of traumatic reticuloperitonitis in bovines. Indian Journal of Animal Science, 80(7), 608-612.

Barros, I. O. (2016). Resposta inflamatória em asininos (Equus asinus) submetidos à ovariequitomia. Tese de doutorado, Universidade Federal Rural do Semi-Árido, Mossoró, RN, Brasil. Recuperado de http:// bdtd.ufersa.edu.br/handle/tede/677

Borkowski, J., Gmyrek, G. B., Madej, J. P., Nowacki, W., Goluda, M., Gabryś, M. S.,... Chełmońska-Soyta, A. (2008). Serum and peritoneal evaluation of vitamin D-binding protein in women with endometriosis. Postepy Higieny I Medycyny Doswiadczalnej, 62, 103-109.

Braun, U., Beckmann, C., Gerspach, C., Hassig, M., Muggli, E., Knubben-Schweizer, G., \& Nuss, K. (2012). Clinical findings and treatment in cattle with caecal dilatation. Veterinary Research, 8(75), 1-9. doi: 10. 1186/1746-6148-8-75

Câmara, A. C. L., Afonso, J. A. B., Costa, N. A., Mendonça, C. L., Souza, M. I., \& Borges, J. R. J. (2010). Fatores de risco, achados clínicos, laboratoriais e avaliação terapêutica em 36 bovinos com deslocamento de abomaso. Pesquisa Veterinária Brasileira, 30(5), 453-464. doi: 10.1590/S0100-736X 2010000500014

Campos, A. G. S. (2014). Estudo hematológico e proteinograma sanguíneo e do colostro de ovelhas suplementadas com propilenoglicol e com cobalto associado à vitamina b12 e de suas respectivas crias. Tese de doutorado, Universidade Federal Rural de Pernambuco,Recife, PE, Brasil. Recuperado de http://bdtd.ibict.br/vufind/ Record/URPE_6838ebc9db2d64ad9fe80 ad64b5c230a
Ceciliani, F., Ceron, J. J., Eckersall, P. D., \& Sauerwein, H. (2012). Acute phase proteins in ruminants. Journal of proteomics, 75(14), 4207-4231.

Chan, J. P. W., Chang, C. C., Hsu, W. I., Liu, W. B., \& Chen, T.H. (2010). Association of increased sérumacute-phaseproteinconcentrations with reproductive performance in dairy cows with postpartum metritis. Veterinary Clinical Pathology, 39(1), 72-78. doi: 10.1111/j.1939-165X.2009.00182

Collins, T. (2000). Inflamação aguda e crônica. In R. S. Cotran, V. Kumar, T. R. Colins (Eds.), Patologia estrutural e funcional (6a ed., pp. 44-78). Rio de Janeiro: Guanabara Koogan.

Conceição, W. L. F., Clemente, V., Silva, D. G., Rocha, T. G., Chaves, D. P., \& Fagliari, J. J. (2015). Proteinograma sérico de vacas das raças Nelore e Girolando sororreagente ou não à brucelose e à leptospirose, no Estado do Maranhão, Brasil. Revista Portuguesa de Ciências Veterinárias, 110, 221-225.

Conner, J. G., Eckersall, P. D., Wiseman, A., Aitchison, T. C., \& Douglas, T. A. (1988). Bovine acute phase response following turpentine injection. Research in Veterinary Science, 44(1), 82-88. doi: 10.1016/00 345288(88)90018-5

Dewhurst, E., \& Papasouliotis, K. (2005). Body cavity effusions. In E. Villiers, \& L. Blackwood (Eds.), BSAVA manual of canine and feline clinical pathology (2a ed., pp. 340-363). Quedgeley. Inglaterra: British Small Animal Veterinary Association.

Dezfouli, M. R. M., Lotfollahzadeh, S., Sadeghian, S., Kojouri, G. A., Eftekhari, Z., Khadivar, F., \& Bashiri, A. (2012). Blood electrolytes changes in peritonitis of cattle. Comparative Clinical Pathology, 21(6), 1445-1449. doi: 10.1007/s00580011-1312-6 
Dirksen, G., Gründer, H. D., \& Stöber, M. (1993). Rosenberger: exame clínico dos bovinos (3a ed.) Rio de Janeiro: Guanabara Koogan.

Divers, T. J., Peek, S. F. (2008). Rebhun's. Diseases of Dairy Cattle (2a ed.). St. Louis, Missouri. Saunders Elsevier.

Eckersall, P. D. (2000). Recent advances and future prospects for the use of acute phase proteins as markers of disease in animals. Revista de Medicina Veterinária, 151(7), 577-584.

Eckersall, P. D. (2008). Proteins, proteomics, and the dysproteinemia. In J. J. Kaneko, J. W. Harvey, \& M. L. Bruss (Eds.), Clinical biochemistry of domestic animals (6nd ed., pp. 117-155). Glasgow: Academic Press.

Eckersall, P. D., \& Bell, R. (2010). Biomarkers of infection and inflammation in veterinary medicine. The Veterinary Journal, 185(1), 23-27. doi: 10.1016/j.tvjl.2010.04.009

Eckersall, P.D., Young, F. J., Mccomb, C., Hogarth, C. J., Safi, S., Weber, A.,... Fitzpatrick, J. L. (2001). Acute phase protein in serum and milk from dairy cows with clinical mastitis. Veterinary Record, 148(2), 35-41. doi: 10.1136/vr.148.2.35

Fagliari, J. J., \& Silva, S. L. (2002). Hemograma e proteinograma plasmático de equinos hígidos acometidos por abdômen agudo, antes e após laparotomia. Arquivo Brasileiro de Medicina Veterinária e Zootecnia, 54(6), 559-586. doi: 10.1590/ S0102-09352002000600001

Grönlund, U., Sandgren, C. H., \& Persson, W. K. (2005). Haptoglobin and serum amyloid $A$ in milk from dairy cows with chronic subclinical mastitis. Veterinary Research, 36(2), 191-198. Retrieved from https:// hal.archives-ouvertes.fr/hal-00902966/ document
Grosche, A., Furll, M., \& Wittek, T. (2012). Peritoneal fluid analysis in dairy cows with left displaced abomasum and abomasal volvulus. Veterinary Record, 170 (16), 413. doi: 10.1136/vr.100381

Gruys, E., Obwolo, M. J., \& Toussaint, M. J. (1994). Diagnostic significance of the major acute phase proteins in the veterinary clinical chemistry: a review. The Veterinary Bulletin, 64, 1009-1018.

Habasha, F. G., \& Yassein, S. N. (2014). Advance techniques in traumatic reticuloperitonitis diagnosis: reviews. AL-Qadisiya Journal of Veterinary Medicine Science, 13(2), 50-57. doi: $10.29079 /$ vol13 iss 2 art302

Harvey, J. W. (2012). Hematology procedures. In J. W. Harvey (Eds.), Veterinary hematology. A diagnostic guide and color atlas (pp. 1132). St. Louis: Elsevier.

Heegaard, P. M. H., Godson, D. L., Toussaint, M. J. M., Tjornehoj, K., Larsen, L. E., Viuff B., \& Ronsholt, L. (2000). The acute phase response of haptoglobin and serum amyloid $A$ (SAA) in cattle undergoing experimental infection with bovine respiratory syncytial virus. Veterinary Immunology and Immunopathology, 77(1-2), 151-159. doi: 10.1016/s01652427(00)00226-9

Hirsch, V. M., \& Townsend, H. G. G. (1982). Peritoneal fluid analysis in the diagnosis of peritoneal disorders in cattle. A retrospective study. The Canadian Journal of Veterinary Research, 23(12), 348-354.

Hirvonen, J. (2000). Acute phase response in dairy cattle. Tese de doutorado. Recuperado de http://ethesis. helsinki.

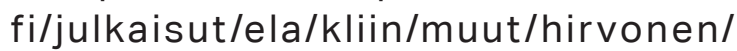
introduction.html

Hirvonen, J., \& Pyörälä, S. (1998). Acute phase response in dairy cows with surgicallytreated abdominal disorders. The 
Veterinary Journal, 155(1), 53-61. doi: 10.1016/S1090-0233(98)80036-1

Hussain, S. A., \& Uppal, S. K. (2014). Haematobiochemical changes and peritoneal fluid cytology in clinical cases of bovine peritonitis. Indian Journal of Animal Research, 48(2), 188-193. doi: 10.5958/j. 0976-0555.48.2.039

Hussain, S. A., Uppal, S. K., Randhawa, C. S., Sood, N. K., \& Bovine, N. K. S. (2015). Bovine intestinal obstruction: blood gas analysis, serum C-reactive protein and clinical, haematological and biochemical alterations. Journal of Applied Animal Research, 43(2), 224-230. doi: 10.1080/09712119.2014.963093

Jain, N. C. (1993). Essentials of veterinary hematology. Philadelphia: Lea \& Febinger.

Jawor, P., Stefaniak, T., Steiner, S., \& Baumgartner, W. (2009). Dynamics of selected acute phase proteins in surgical abomasal reposition in cows. Folia Veterinaria, 53(1), 18-21.

Jawor, P., Steiner, S., Stefaniak, T., Baumgartner, W., \& Rzasa, A. (2008). Determination of selected acute phase proteins during the treatment of limb diseases in dairy cows. Veterinary Medicine-Czech, 53(4), 173183.

Jones, T. C., Hunt, R. D., \& King, N. W. (2000). Distúrbios da circulação. Patologia veterinária (6a ed., pp. 167-184). São Paulo: Manole.

Kaneko, J. J., Harvey, J. W., \& Bruss, M. L. (2008). Clinical biochemistry of domestic animals (6nd ed.). New York: Academic Press.

Laemmli, U. K. (1970). Cleavage of structural proteins during the assembly of the head of bacteriophage T4. Nature, 227(5259), 680-685.
Lascelles, B. D. X. (1996). Advances in the control of pain in animals. Veterinary Annual, 36, 1-15.

Lemos, V. F. (2011). Proteinograma do Soro Sanguíneo e Lácteo de Ovelhas da Raça Santa Inês em Diferentes Fases da Lactação. Dissertação de Mestrado, Universidade Federal Rural de Pernambuco, Garanhuns, PE, Brasil. Recuperado de http://www.tede2.ufrpe. br:8080/tede2/bitstream/tede2/6303/2/ Vania\%20Freire\%20Lemos.pdf

Macedo, A. T. M., Souto, R. J. C., Mendonça, C. L., Fagliari, J. J., Silva, P. C., Soares, P. C., \& Afonso, J. A. B. (2017). Proteinograma de ovelhas acometidas por casos naturais de toxemia da prenhez. Veterinária e Zootecnia, 24(1), 159-173.

Maden, M., Ozturk, A. S., Bulbul, A., Avci, G. E., \& Yazar, E. (2012). Acute-phase proteins, oxidative stress and enzyme activities of blood serum and peritoneal fluid in cattle with abomasal displacement. Journal of Veterinary Internal Medicine, 26(6), 470-1475. doi: 10.1111/j.19391676.2012.01018

Mendes, L. C. N., Peiró, J. R., Feitosa, F. L. F., Luvizotto, M. C. R., Borges, A. S., Ciarlini, P. C., \& Perri, S. H. V. (2005). Effect of age and abomasal puncture on peritoneal fluid, hematology, and serum biochemical analyses in young calves. Journal of Veterinary Internal Medicine, 19(6), 899904. doi: 10. 1111/j.1939-1676.2005. tb02785.x

Moore, D. F., Rosenfeld, M. R., Gribbon, C., Winlove, P., \& Tsai, C. M. (1997). Alpha-1-acid (AAG, orosomucoid) glycoprotein: interaction with bacterial lipopolysaccharide and protecion from sepsis. Inflamation, 21(1), 69-82. doi: 10.1023/a:1027342909423 
Murata, H., Shimada, N., \& Yoshioka, M. (2004). Current research on acute phase proteins in veterinary diagnosis: an overview. The Veterinary Journal, 168(1), 28-40. doi: 10.1016/s1090-0233(03)00119-9

Nogueira, A. F. S., Di Filippo, P. A., Anai, L. A., Pereira, G. T., \& Santana, A. E. (2013). Proteinograma sérico e do líquido abdominal de equinos hígidos e daqueles submetidos à obstrução intestinal experimental. Ciência Rural, 43(11), 2018-2024. doi: 10.1590/S010384782013001100016

Nogueira, A. F. S., Di Filippo, P. A., Santana, A. E., Anai, L. A.,Sanata A. E., \& Campos, E. Fo. (2010). Concentração das proteínas de fase aguda negativas no soro sanguíneo e no líquido peritoneal de equinos submetidos à cólica experimental. Anais do Congresso Associação Brasileira dos Médicos Veterinários de Equídios, ABRAVEQ, São Paulo, SP, Brasil.

Peiró, J. R., Lucato, B., Mendes, L. C. N., Ciarlini, P. C., Feitosa, F. L. F., Bonelho, F. L.,... Perri, S. H. V. (2009). Evaluation of cytologic and biochemical variables in blood, plasma, and peritoneal fluid from calves before and after umbilical herniorraphy. American Journal of Veterinary Research, 70(3), 423-432. doi: 10.2460/ajvr.70.3.423

Radostits, O. M., Gay, C. C., Hinchcliff, K. W., \& Constable, P. D. (2007). Veterinary medicine. A textbook of the diseases of cattle, horses, sheep, pigs, and goats. Edinburgh: Saunders Elsevier.

Reddy, L. S. S. V. P., Reddy, B. S., Naik, B. R., \& Prasad, C. S. (2014). Haematological and clinical alterations with traumatic reticuloperitonitis in cattle. International Journal of Veterinary Science, 3(4), 203205.
Russell, K. E., \& Roussel, A. J. (2007). Evaluation of the ruminant serum chemistry profile. Veterinary Clinics of North America Food Animal Practice, 23(3), 403-426. doi: 10.1016/ j.cvfa.2007.07.003

Statistical Analyses Sistem Institute (2009). SAS user's guide. Statics Version. SAS. Cary, N. C.: SAS Institute.

Saut, J. P. E., Souza, R. M., Birgel, D. B., Pogliani, F. C., Cavalcante, C. Z., Miyashiro, S. I., ... Birgel, E. H., Jr. (2009). Influência do puerpério sobre o proteinograma sérico de caprinos da raça Saanen obtido por eletroforese em gel de poliacrilamida. Semina: Ciências Agrárias, 30(3), 661-70.

Segelmark, M., Persson, B., Hellmark, T., \& Wieslandes, J. (1997). Binding and inhibition of myeloperoxidase (MPO): a major function of ceruloplasmin? Clinical \& Experimental Immunology, 108(1), 167174. doi: 10.1046/j.1365-2249.1997.d01992.x

Silva, A. P., Fo., Afonso, J. A. B., Souza, J. C. A., Costa, N. A., \& Mendonça, C. L. (2010). Análise clínica e patológica em 20 casos de intussuscepção em bovinos. Veterinária e Zootecnia, 17(3), 421-430.

Silva, G. D., Lacerda, S. P. R., Silva, P. C., \& Fagliari, J. J. (2011). Serum protein concentrations, including acute phase proteins, in calves experimentally infected with Salmonella Dublin. Pesquisa Veterinária Brasileira, 31(7), 551-554. doi: 10.1590/S0100736X2011000700001

Silva, N. A. A. (2011). Achados epidemiológicos, clínicos e ultrassonográficos em bovinos acometidos com retículopericardite traumática. Dissertação de mestrado, Universidade Federal Rural de Pernambuco. Garanhuns., Garanhuns, PE, Brasil. Recuperadode http://www.tede2. ufrpe.br:8080/tede/handle/tede2/ 6275 
Simplício, K. M. M. G. (2011). Leucograma e proteínas de fase aguda de ruminantes domésticos sadios e enfermos. Dissertação de mestrado, Universidade Estadual Paulista, Jaboticabal, São Paulo, Brasil. Recuperado de https://repositorio. unesp.br/handle/11449/89231

Simplício, K. M. M. G., Sousa, F. C., Fagliari, J. J., \& Silva, P. C. (2013). Proteinograma sérico, com ênfase em proteínas de fase aguda, de bovinos sadios e bovinos portadores de enfermidade aguda de ocorrência natural. Arquivo Brasileiro de Medicina Veterinária e Zootecnia, 65(5), 1339-1347. doi: 10.1590/S010 2-09352013000500011

Smith, B. P. (2015). Large animal internal medicine (5nd ed.). St Louis: Mosby.

Soares, G. T. (2008). Concentrações plasmática e peritoneal de proteínas de fase aguda em bezerros portadores de hérnias umbilicais. Dissertação de mestrado, Universidade Estadual Paulista, Araçatuba, SP, Brasil. Recuperado de https://repositorio.unesp. br/handle/11449/92202

Tharwat, M., Ali, A., Al-Sobayila, F., \& Buczinskib, S. (2013). Ultrasound-guided collection of peritoneal fluid in healthy camels (Camelus dromedarius) and its biochemical analysis. SmallRuminantResearch, 113(1), 307-311. doi: 10.1016/j.smallrumres.2013.04.002
Tóthová, C., Nagy, O., Kovac, G., \& Janciauskiene, S. (2013). The use of acute phase proteins as biomarkers of diseases in cattle and swine. Acute Phase Proteins, 103, 138. doi: $10.5772 / 55857$

Tóthová, C., Nagy, O., \& Kovac, G. (2014). Acute phase proteins and their use in the diagnosis of diseases in ruminants: a review. Veterinární Medicina, 59(4), 163180. doi: 10.17221/7478-vetmed

Wittek, T., Grosche, A., Locher, L. F., Alkaassem, A., \& Furll, M. (2010a). Biochemical constituents of peritoneal fluid in cows. The Veterinary Record, 166(1), 15-19. doi: 10.1136/vr.b5584

Wittek, T., Grosche, A., Locher, L. F., \& Furll, M. (2010b). Diagnostic accuracy of d-dimer and other peritoneal fluid analysis measurements in dairy cows with peritonitis. Journal of Veterinary Internal Medicine, 24(5), 1211-1217. doi: 10.1111/j.1939-1676.2010.0548.x

Zadnik, T. (2010). A retrospective study of peritoneal fluids in cows with peritoneal disorders. Veterinarski Glasnik, 64(3-4), 187-195. doi: 10.2298/vetgl1004187t 
